\title{
> Por uma esquizoanálise das narrativas de estupro: uma leitura de Mar azul (2012), de Paloma Vidal
}

\author{
> For a schizoanalysis of rape narratives: \\ a reading of Paloma Vidal's Mar azul (2012)
}

\section{por Karine Mathias Döll}

Doutoranda em Letras/Estudos da Literatura na linha de pesquisa Teoria, Crítica e Comparatismo do Programa de Pós-Graduação em Letras da Universidade Federal do Rio Grande do Sul (UFRGS). E-mail: karinemdoll@gmail.com. ORCID: 0000-0002-7091-6511.

\section{Resumo}

O objetivo deste trabalho, ao aproximar a filosofia de Deleuze e Guattari da escrita literária de Paloma Vidal na obra Mar azul (2012), é propor pontos de contato em meio a um campo de interesse dos autores (a saber, a literatura), culminando numa discussão possível das figurações do estupro na literatura. Para tanto, buscou-se apresentar o romance atrelando-o aos conceitos de desterritorialização e reterritorialização a fim de se pensar a produção da mulher-corpo em detrimento da mulher-mente, bem como noções de rostidade e plano de imanência em meio ao que poderíamos chamar de "cultura do estupro". Em seguida, discute-se o conceito de "corpo sem órgãos" a partir do campo literário e suas estratificações canônicas.

Palavras-chave: Narrativas de estupro. Literatura brasileira. Filosofia francesa contemporânea.

\begin{abstract}
The aim of this work, by bringing together the philosophy of Deleuze and Guattari to the literary writing of Paloma Vidal in the novel Mar azul (2012), is to propose contact points in the middle of a field of interest to the authors (namely, literature), culminating in a possible discussion of rape figures in literature. To this end, it was sought to present the novel linking it to the concepts of deterritorialization and reterritorialization in order to think about the production of the woman-body at the expense of the woman-mind, as well as notions of rostity and plan of immanence in the midst of what we could call "rape culture". Then, the concept of "body without organs" is discussed as from the literary field and its canonical stratifications.
\end{abstract}

Keywords: Rape Narratives. Brazilian Literature. Contemporary French Philosophy. 
Vocês serão alfinetados no muro branco, cravados no buraco negro.

Gilles Deleuze e Félix Guattari

\section{Introdução}

Este trabalho ${ }^{1}$ parte de um delírio. Um delírio enquanto medida da saúde, de que fala Gilles Deleuze ${ }^{2}$, pois, se é concebível que pensemos a literatura como delírio, enquanto algo que não se ajusta à realidade, ou não quer se ajustar, ao mesmo tempo que faz uso dela, é concebível, por sua vez, que pensemos o esforço para uma análise de narrativas de estupro em obras literárias também como um delírio: o delírio de se analisar algo insólito que é, no mais das vezes, tomado como trivial. A essa altura, pode parecer que o delírio de que falo se distancie um pouco do delírio empreendido por Deleuze e se aproxime de um delírio psicanalítico, edipiano, que nada tem a ver com as discussões propostas, mas é essa justamente a questão do estupro. A narrativa (ou as narrativas, apesar de que tratarei apenas de uma, uma entre tantas) de estupro transita neste entre-lugar em que os dois pólos do delírio propostos por Deleuze encontram-se: o delírio de dominação e o delírio bastardo. Ou seja, a doença e a medida da saúde, respectivamente. No entanto, tomo o delírio bastardo como chave de leitura para a análise que aqui se inicia, pois é a partir dele que podemos relativizar o trivial e ir ao encontro de uma possibilidade de vida em meio aos delírios de dominação que não são poucos. Tomo o delírio bastardo como norte para este trabalho pois é ele que "invoca essa raça bastarda oprimida que não para de agitar-se sob as

\footnotetext{
${ }^{1}$ Artigo escrito para a disciplina de "Literatura e filosofia", ofertada pelo Programa de PósGraduação em Estudos da Linguagem da Universidade Estadual de Ponta Grossa (UEPG) e ministrada pela prof ${ }^{a}$. Dr ${ }^{a}$. Silvana Oliveira, entre os meses de agosto a dezembro de 2017.

${ }^{2}$ Gilles Deleuze, Crítica e clínica, 2011.
} 
dominações, de resistir a tudo o que esmaga e aprisiona e de, como processo, abrir um sulco para si na literatura"3. O delírio bastardo como medida da saúde invoca também "agenciamentos coletivos de enunciação" que operam de forma maquínica dentro da literatura, ela mesma, por sua vez, também máquina abstrata.

Nesse sentido, penso nos regimes de signos e nos traços de rostidade específicos, que também são abordados por Deleuze, em diálogo com Guattari. ${ }^{4}$ Haja vista seus centros de significância e pontos de subjetivação, no que diz respeito à discussão do estupro na literatura, são estes mesmos regimes e traços que fazem com que as máquinas trabalhem mais rápido e numa escala de intensidade maior. Penso na organicidade de um enunciado sempre redundante, sempre ancorado em um rosto histórico-mundial, num devir-homem que não existe. Então, me faço a seguinte pergunta: de que forma é possível aliar a filosofia de Deleuze e Guattari e as narrativas de estupro na literatura, sem riscos de perda tanto de um lado quanto de outro? Em razão disso, selecionei apenas um romance que tem, como seu fundamento, a narrativa de estupro, ainda que em nenhum momento da obra esta palavra, que é ela já quase uma violação, seja nominada. O romance em questão, portanto, intitulado $\mathrm{Mar}$ azul ${ }^{5}$ e escrito por Paloma Vidal é o corpus da análise, que se fará presente mais especificamente na primeira seção do artigo, em que apresento a obra e proponho uma leitura do romance a partir dos conceitos de plano de imanência, rostidade e desterritorialização. A seleção desses conceitos deu-se pela evidente correlação do objeto de análise com a proposta da esquizoanálise e, principalmente, pelo

\footnotetext{
${ }^{3}$ Ibidem, p. 15.

${ }^{4}$ Gilles Deleuze e Félix Guattari, Mil platôs: capitalismo e esquizofrenia 2 - v. 3, 2012.

${ }^{5}$ Paloma Vidal, Mar azul, 2012.
} 
estupro estar inserido num plano de imanência, não escapar da máquina abstrata de rostidade e agenciar desterritorializações, bem como reterritorializações. Num segundo momento, e de maneira breve e introdutória, dedico a outra seção à prática do corpo sem órgãos como exercício de empatia para com a narrativa de estupro, uma vez que, se o corpo sem órgãos vem a ser o real em seu mais alto grau, é preciso que se entenda "o que povoa, o que passa e o que bloqueia" uma tal narrativa, com o intuito de desestratificá-la, desestratificando os enunciados que a envolvem.

Por fim, pretende-se com este trabalho que as narrativas de estupro sejam lidas de forma a questionar o sistema muro branco-buraco negro, ou seja, não parta de uma unificação que levaria a sua imperceptibilidade ou de uma consciência sobreposta a qualquer espécie de devir, mas que incentive os leitores a procurarem "seus buracos negros e seus muros brancos, conheçam-nos, conheçam seus rostos, [pois] de outro modo vocês não os desfarão, de outro modo não traçarão suas linhas de fuga" ${ }^{\text {. }}$

\section{I.}

“Isto não é um diário, nem uma carta, nem uma autobiografia, nem qualquer outro modo de escrita íntima. Só escrevo porque ele escreveu do outro lado"7 . É com essas palavras que Paloma Vidal inicia o capítulo 14 de seu romance Mar azul. E é com essas palavras que inicio esta seção para caracterizar brevemente a obra. O romance de que vou tratar inscreve-se em dois momentos.

\footnotetext{
${ }^{6}$ Gilles Deleuze e Félix Guattari, Op. Cit., 2012, p. 64.

${ }^{7}$ Paloma Vidal, Op. Cit., 2012, p. 74.
} 
No primeiro deles, temos uma espécie de prólogo e epílogo durante os quais duas amigas conversam. No segundo momento, em que o romance passa a ser dividido em capítulos, ficamos sabendo que uma das amigas se chama Vicky e que a outra vem a ser a protagonista, autora do trecho que inicia este parágrafo, e cujo nome não sabemos. Cada capítulo parece dar conta de um dia na vida da protagonista, em que rotina e reminiscências formam um elo com os escritos anteriores aos dela que ali se encontravam, uma vez que os cadernos azuis em que escreve um dia pertenceram ao seu pai e só foram parar nas mãos da protagonista em função de herança. Dessa forma, na afirmação "Só escrevo porque ele escreveu do outro lado", é possível estabelecer dois aspectos distintos da escrita de cada um. Para o pai, os cadernos serviam como remédio para uma doença que o consumia com a memória dia após dia e, portanto, era necessário que escrevesse: para lembrar. Para ela, os cadernos atestavam uma lucidez insistente, mesmo que se encontrasse já em idade mais avançada, e permitiam o encurtamento de uma distância que atravessou toda a sua vida, a partir do momento em que seu pai foi embora e a deixou na casa de Vicky, aos cuidados de uma mãe que não era a sua. Porém, o que se percebe nessa escrita da protagonista é que ela, em oposição às composições de seu pai, poderia com destreza confiar nas certezas que a memória lhe permitia, o que justamente ela não queria e a todo momento em que uma lembrança parece se impor no meio de uma composição sua, lança-se uma ruptura seguida da descrição de uma série programada das coisas práticas que ela deveria fazer ou fez naquele dia. Ou seja, era necessário também que escrevesse: para esquecer. Isso fica claro logo no capítulo 1, em que afirma: 
Por mais que me esforce para não lembrar é o que faço o dia inteiro. Tantas horas preocupada em fazer perdurar os acontecimentos e agora que é o momento de esquecer minha mente parece obstinada em reter tudo até $o$ final. A dele acabou se tornando opaca. Eu aguardo que chegue minha vez e tento identificar os primeiros sinais de uma desconexão que se demora ${ }^{8}$.

Essa percepção das duas possibilidades de escrita distintas atuando nos mesmos cadernos leva-nos a perguntar o que exatamente ela queria esquecer e, para tanto, é preciso que voltemos ao diálogo inicial que abre o romance. Neste diálogo, além das referidas personagens, temos também a figura de $\mathrm{R}$, o então "namorado" da protagonista quando ainda estava na escola. Ela, com apenas trezes anos à época, acaba por enredar-se na história desse rapaz que a domina e subjuga, sem conseguir desvencilhar-se. O diálogo vai apresentando-se como trechos de conversa entre duas amigas, que geram um certo desconforto nos leitores por bem retratar o desconforto sentido pela própria protagonista. A título de exemplo, cito um dos trechos:

- Quem disse que as pessoas decidem ter filhos?

- Por que você tá dizendo isso?

- Porque é assim.

- Você quer ter filhos?

- Ele me perguntou o que eu acho sobre isso.

- E aí?

- Fiquei calada.

- Pelo visto é sempre ele que fala.

- Ele fala muito mesmo.

- E por que será que ele tocou nesse assunto?

- Foi do nada. Ele disse que pra ser mãe a gente tem que estar pronta pro sacrifício.

- Minha mãe tinha que ouvir isso.

- Ele falou da sua mãe.

- O que foi que ele disse?

- Que ele não entende pra que ela teve você.

${ }^{8}$ Ibidem, p. 41-42. 
- Não acredito que ele falou isso, ele não sabe nada da minha mãe.

- Ele falou sobre a Virgem Maria, ficou falando da pureza dela. Ele tava querendo me dizer alguma coisa, não entendi direito.

- Esse cara, não sei, toma cuidado.

- Você sempre diz isso.

- Você gosta dele?

- Como é que a gente sabe uma coisa dessas ${ }^{9}$ ?

É importante destacar uma vez mais que todo o diálogo inicial funciona como uma espécie de prólogo da obra que virá, uma vez que o romance de fato tem seu início pelo capítulo 1 que começa após esse diálogo. Nesse sentido, deduzimos que $\mathrm{R}$ vem a ser este personagem presente em todo o diálogo por meio de pequenas incursões da própria narradora ao longo do texto subsequente, estando a primeira no capítulo 11 , que cito a seguir:

Será que consigo escrever o nome dele? Não, vou chamá-lo de R, e vou contar uma coisa que nunca contei a ninguém: um dia ele achou num livro meu a foto da minha mãe nua e me disse bem baixinho, como se fosse um segredo nosso, que minha mãe era uma puta e que se eu não me cuidasse ia acabar como ela. Depois guardou a foto no bolso da calça e eu nunca mais $\mathrm{vi}^{10}$.

No entanto, ao acompanharmos o desencadeamento de uma experiência traumática vivida pela protagonista em seu relacionamento com $\mathrm{R}$ no decurso de todos os diálogos, o final deles culmina num episódio que parecia estar sempre à espreita para, nós, leitores, e nunca para a protagonista. As últimas falas do trecho de conversa final são intercaladas por uma Vicky angustiada de terror pela

\footnotetext{
${ }^{9}$ Ibidem, p. 20.

${ }^{10}$ Ibidem, p. 67.
} 
amiga que, muda, não conseguia dizer mais senão as próprias falas de $\mathrm{R}$, como é possível verificar a seguir:

- Ele fez questão de mostrar um monte de coisas, sua coleção de medalhas, uma caricatura que alguém fez dele, e disse que era assim que ele se via, que não gosta de quem ele é, e continuou falando, mas eu não disse nada, muda, eu tava muda, o tempo todo, muda.

- Vira pra cá, para com isso, comigo você pode falar.

- Muda, o tempo todo.

- Para com isso, por favor, fala comigo.

- Acabou.

- Eu vou ficar com você.

- Fala, você tá gostando, né?

- O que você tá dizendo, vira pra cá.

- Devagar, devagar, assim, eu vou fazer bem devagar, você nem vai sentir nada.

- O que você tá dizendo, pelo amor de deus.

- Eu te seguro assim, tá, fica com as mãos bem quietinhas aqui atrás, juntinhas, minha freirinha, não vai doer, você fica assim deitada, vira pro outro lado, eu vou tirar isso aqui, não, não se mexe, é só um empurrãozinho, você vai sentir, mas não é nada, assim, só vai doer um pouquinho, mas você vai gostar, não tá gostando, fala, não tá gostando?

- Para com isso, vira pra cá, por favor, olha pra mim. Você tá me deixando assustada.

- Fecha os olhos, isso, tá gostando, né? Eu mexo assim, devagarinho. Por trás é que é bom. Não chora, minha putinha, você queria, eu sei, eu sei, não finge que não, não me empurra assim, putinha, vem cá, fica quieta, tá bom? Tá tudo bem, né? Eu estou gostando muito. Você é minha, minha, só minha, assim não vai doer, isso, agora se mexe, vamos, não chora e se mexe, só um pouco, isso, quer mais forte, assim, né? Para de chorar e se mexe, já estou quase acabando, eu não quero te machucar, você sabe, eu quero o melhor pra você, eu quero te ensinar um monte de coisas, você é tão burra, mas eu vou te ensinar, tudo, tudinho, mas agora se mexe, vamos, bem fechadinha, isso, bem apertadinha, só pra mim, só minha, do jeito que eu mandar, assim, assim, isso, não chora, não chora, assim, se mexe assim, minha putinha, assim, assim, agora eu estou em você pra sempre ${ }^{11}$.

${ }^{11}$ Ibidem, p. 40. 
A mudez, aliás, é um tema recorrente ao longo das páginas que vão sendo escritas pela protagonista. Sabemos que adquiriu uma timidez e um silêncio que não lhe eram característicos quando ainda vivia com o pai, como mostra também este trecho:

Minha precocidade era denunciada como defeito, e quando ele me imputava não ser capaz de ficar em silêncio nem quando estava sozinha era tal a sua incompreensão que só me restava uma espécie de culpa pela minha opacidade, que com o tempo acabou virando uma timidez irremediável ${ }^{12}$.

E a essa timidez irremediável uniu-se um outro tipo de silêncio, um "silêncio eloquente"13, e é a partir dele que podemos convergir os dois termos necessários para que se comece a traçar uma linha de desterritorialização absoluta dentro do romance. Os termos são corpo e mente, um dualismo que, à primeira vista, pode parecer cartesiano demais para os propósitos do artigo, mas que funciona perfeitamente quando associado à figura da mulher, a sua percepção enquanto sujeito e, em última instância, ao estupro. A desterritorialização sugerida na trajetória da personagem implica na desterritorialização do próprio corpo na medida em que o corpo não prevê fala, não prevê nome e não prevê história. “[...] fazer as travessias que o corpo precisa

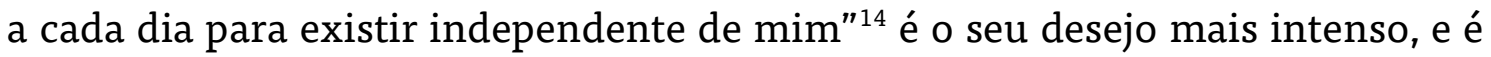
por ele que a protagonista vai encaminhando seu relato. Ao finalizar o diálogo que dá início ao romance com uma narrativa de estupro, já sabemos haver uma descontinuidade, e quando falo em desterritorialização partindo dessa

\footnotetext{
${ }^{12}$ Ibidem, p. 74-75.

${ }^{13}$ Ibidem, p. 51.

${ }^{14}$ Ibidem, p. 48.
} 
descontinuidade a redundância é necessária. Mas voltemos ao conceito, em que a desterritorialização encaminha para uma reterritorialização dos termos um sobre o outro. Ou seja, o corpo será reterritorializado sobre a mente que, por sua vez, passará pelo mesmo processo, em algum momento, sobre o corpo. Nesse sentido, a mente, ao reterritorializar-se sobre o corpo, age sob a forma das lembranças, o que não deve ser confundido como um retorno a uma territorialidade primitiva, mas, sim, ao próprio retorno à desterritorialização, como num ciclo.

Talvez seja possível, então, pensar em três momentos distintos que se complementam: 1) o momento da territorialidade primitiva: o estupro, em que ainda encontramos mente sobre o corpo, uma vez que "o corpo mal sabia de sua existência"; 2) o momento da desterritorialização: o abandono, ou o extravio de si pelo silêncio e esquecimento, em que o corpo passa a atuar sobre a mente; 3) o momento da reterritorialização: o corpo como possibilidade de vida, em que é preciso continuar e seguir uma rotina, ou uma "série programada", em que elementos como a caminhada, a natação, as idas às consultas médicas fazem do corpo essa engrenagem necessária e preponderante. No entanto, a lembrança é o motor que faz essa máquina girar, de modo que a mente por vezes se sobressai de forma inoportuna e estados como os de "imobilização" ou "concentração deslocada" remontam ao estupro, que remontam ao corpo, que remontam às coisas práticas que precisam ser executadas. É o que tentarei mostrar com o trecho a seguir, continuação de um trecho já citado anteriormente extraído do capítulo 11 , em que a protagonista fala sobre $\mathrm{R}$ ao deparar-se com a foto de sua mãe nua: 
Uma manhã que começa com uma lembrança dessas está certamente comprometida. Às vezes me vem uma imagem dele e eu faço um gesto rápido com a mão sobre a cabeça, como se quisesse espantar um inseto.

Hoje vou sair cedo, não importa o que insinuem os pensamentos que me assombram. Vou sair cedo, virar a esquina devagar, até a banca de jornal. Vou comprar algo. Quero pedir uma coisa e que ela esteja ao meu alcance. E depois quero segurar essa coisa entre as mãos e dizer obrigada por ela. Pagar e continuar andando ${ }^{15}$.

Agora, é preciso pensar nos "teoremas de desterritorialização" propostos por Deleuze e Guattari. ${ }^{16}$ O primeiro deles fala sobre um sistema de reterritorializações horizontais e complementares, em que “[...] um elemento, ele mesmo desterritorializado, serve de territorialidade nova ao outro que também perdeu a sua"17. Voltando-se aos objetivos desta análise, é possível dizer que, após a violação, o corpo já não é mais o mesmo corpo, a mente já não é mais a mesma mente, e ambos estão se complementando de forma mútua; desterritorializandose e reterritorializando-se. O segundo teorema fala sobre as diferenças de velocidade e intensidade relativas à desterritorialização de cada termo e, nesse sentido, parece-me evidente que o corpo, neste caso, agrega velocidade e que a mente agrega intensidade, no entanto, nas palavras dos filósofos: “[...] o mais rápido [dos termos] conecta sua intensidade com a intensidade do mais lento, a qual, enquanto intensidade, não o sucede, mas trabalha simultaneamente sobre um outro estrato ou sobre um outro plano" ${ }^{18}$, que, aqui, atuará também sobre o plano de rostidade que veremos mais a frente. $\mathrm{O}$ terceiro teorema contrapõe o primeiro, por tratar-se agora de um sistema de reterritorializações diferente,

\footnotetext{
${ }^{15}$ Ibidem, p. 67.

${ }^{16}$ Gilles Deleuze e Félix Guattari, Op. Cit., 2012.

${ }^{17}$ Ibidem, p. 45.

${ }^{18}$ Ibidem, p. 46.
} 
"vertical, de baixo para cima", em que o menos desterritorializado dos termos - o corpo - reterritorializa-se sobre o mais desterritorializado - a mente. A justificativa para que o corpo seja o menos desterritorializado quando comparado à desterritorialização da mente se dá pelo próprio predomínio daquele na trajetória de nossa protagonista: a mente precisa se estabelecer em outro lugar; o corpo só passou a ser descoberto. O quarto e último teorema diz respeito à própria máquina abstrata, e o que está em jogo na discussão que proponho acerca da narrativa de estupro é a produção da mulher-corpo, em detrimento da mente. Mas isso não é novidade, como bem apontam Thompson e Gunne sobre o tema:

[...] os mitos sobre o estupro que dominam uma audiência, comunidade ou nação particular ditam a maneira como as narrativas são recebidas. [...] Esses mitos negam à mulher estuprada qualquer subjetividade, uma vez que posicionam ela fora da conversação que, como argumenta Laura Donaldson, acontece entre as subjetividades masculinas ${ }^{19}$.

Não à toa, temos a própria fala de $\mathrm{R}$ no momento em que a violência é engendrada no romance, silenciando o diálogo entre as amigas. Tal recurso narrativo escolhido por Paloma Vidal poderia ser denominado de várias formas para se chegar à narrativa do estupro, mas em função do aporte teórico que me cabe $^{20}$, chamarei sua escolha de apelo a um determinado tipo de plano de imanência.

19 “ [...] the rape myths that dominate a particular audience, community or nation dictate the way in which narratives are received. [...] These myths refuse the raped woman any subjectivity as they position her outside a conversation that, as Laura Donaldson argues, takes place between male subjectivities." Sorcha Gunne e Zoë B. Thompson, Feminism, Literature and Rape Narratives: violence and violation, 2010, p. 8, tradução minha.

${ }^{20}$ Vale ressaltar que a aproximação entre os textos de Deleuze e Guattari com a escrita de Vidal deu-se pela proposta decorrente da disciplina "Literatura e filosofia", cuja ementa propunha leitura aprofundada e discussão de alguns trabalhos dos autores. Para uma análise mais completa 
É claro que o plano de imanência está para a literatura assim como a ficção está para a filosofia, mas pensar a narrativa de estupro em termos deleuzoguattarianos permite situar a discussão em outras instâncias, fugindo, por exemplo, da lógica de regimes de verdade sugerida por Foucault ${ }^{21} \mathrm{em}$ que $\mathrm{o}$ que se leva em conta primordialmente são os mecanismos de poder e não o verdadeiro enquanto imagem de pensamento. É verdade que este se constitui pelos mesmos mecanismos, mas, para além disso, a imagem de pensamento implica num movimento infinito em que não há lugar mais para um sujeito e um objeto senão como conceitos. Por essa razão é que não poderíamos admitir, então, dar um nome ao plano de imanência que envolve a narrativa em questão, tais como "cultura do estupro" ou "patriarcado", ainda que os identifiquemos como componentes importantes da agressão, porque estaríamos denominando conceitos e os conceitos apenas "[...] ladrilham, ocupam ou povoam o plano, pedaço por pedaço, enquanto o próprio plano é o meio indivisível em que os conceitos se distribuem sem romper-lhe a integridade, a continuidade"22. $\mathrm{O}$ que entra em jogo quando invocamos uma imagem de pensamento é que somos orientados por ela, dentro de um plano de imanência que "não para de se tecer, gigantesco tear" ${ }^{\prime 23}$.

\footnotetext{
do trabalho de Vidal, sob um outro ponto de vista que também se dá a partir da narrativa de estupro por ela figurada, Ver: DÖLL, K. M. Gatilho - literatura: as narrativas de estupro na ficção de Paloma Vidal e Sheyla Smanioto. 2019. Dissertação (Mestrado em Estudos da Linguagem) Universidade Estadual de Ponta Grossa, Ponta Grossa, 2019. Disponível em: https://bit.ly/340wssU. Acesso em: 18/04/2020.

${ }^{21}$ Cito como aporte e contraponto para a questão da verdade e seu regime enquanto produção discursiva vinculada às práticas institucionais e de poder a aula inaugural no Collège de France. Michel Foucault, A ordem do discurso: aula inaugural no Collége de France, pronunciada em 2 de dezembro de 1970, 2005.

${ }^{22}$ Gilles Deleuze e Félix Guattari, O que é filosofia? 2010, p. 46.

${ }^{23}$ Ibidem, p. 49.
} 
Assim, à desvalorização social do corpo, do corpo feminino mais especificamente, une-se a noção de máquina abstrata cujos agenciamentos são as peças (os conceitos). Para esta análise, mobilizarei apenas dois conceitos que podem ser evidenciados pela narrativa de estupro proposta pela Paloma Vidal, os quais atravessam o plano de imanência constatado. Um desses conceitos diz respeito tanto à narrativa de estupro quanto à própria filosofia e é a percepção de que o corpo da mulher caracteriza-se por uma passividade imanente e que, como objeto passivo, requer conquista e ocupação. Sobre essa questão, a teórica Elizabeth Grosz afirma:

[...] o corpo é tipicamente visto como passivo e reprodutivo, mas amplamente improdutivo, um objeto sobre o qual podem existir disputas entre seus "habitantes" e outros/exploradores. Seja qual for a intenção ou vontade que ele tenha, elas são consequência direta de intenções animadas, psíquicas. Sua inércia significa que se pode atuar sobre ele, coagi-lo ou constrangê-lo através de forças externas ${ }^{24}$.

Tal passividade pode ser compreendida na narrativa presente em Mar azul pelo próprio funcionamento dos verbos, todos no imperativo: "fica assim deitada", "vira pro outro lado", "não se mexe", "fecha os olhos", "não chora" etc, e o subsequente silenciamento da protagonista. Ao lado dessa noção, outro conceito importante trazido no discurso de $\mathrm{R}$ vem a ser a convicção do prazer sentido pelo homem, que automaticamente se estenderia até o prazer sentido pela mulher; isto é, todas as mulheres desejam ser estupradas. Quem nos ajuda a melhor entender essa percepção sobre as mulheres é o historiador Georges Vigarello, quando afirma que "a visão do prazer apaga a agressividade, impondo

\footnotetext{
${ }^{24}$ Elizabeth Grosz, "Corpos reconfigurados", 2000, p. 59.
} 
o desejo como uma evidência à qual a vítima é confusamente associada" ${ }^{25}$, o que acaba por gerar “uma obscura convicção: a vítima, que deliberadamente já teria se entregado a outro, só poderia consentir" ${ }^{26}$. Sabemos que tal associação do desejo com o ato do estupro em si é levada em conta na narrativa de Vidal quando lemos: "só vai doer um pouquinho, mas você vai gostar", "tá gostando, né?", "você queria, eu sei, eu sei, não finge que não". Susan Brownmiller justifica tal presunção ao afirmar que

Uma vez que o estupro é um ato que homens praticam em nome de suas masculinidades, é do interesse deles que se acredite que as mulheres também querem que se cometa o estupro, em nome da feminilidade. $\mathrm{Na}$ dicotomia que eles estabeleceram, um pratica e o outro "se deixa ser praticado"27.

Sabemos que o que estou denominando aqui de conceitos podem muito bem ser chamados de mitos relativos à cultura do estupro. Entretanto, não deixam de ser conceitos uma vez que também são problemas e "todo conceito remete a um problema, a problemas sem os quais não teria sentido" ${ }^{28} \cdot{ }^{29}$ Dessa

\footnotetext{
${ }^{25}$ Georges Vigarello, História do estupro: violência sexual nos séculos XVI-XX, 1998, p. 30.

${ }^{26}$ Ibidem, p. 31.

27 "Because rape is an act that men do in the name of their masculinity, it is in their interest to believe that women also want rape done, in the name of femininity. In the dichotomy that they have established, one does and one 'is done to'." Susan Brownmiller, Against Our Will: men, women and rape, 1975, p. 312, tradução minha.

${ }^{28}$ Gilles Deleuze e Félix Guattari, Op. Cit., 2010, p. 24.

${ }^{29}$ A maneira como me aproprio da conceitualidade do conceito me leva a inscrever outra relação entre conceito e problema. Entendo que, na primeira parte de O que éfilosofia?, Deleuze \& Guattari constituem uma determinada conceitualidade do conceito que implica na relação criativa e contingencial da filosofia atrelada à investigação de problemas. Desse modo, a criação de conceitos para os autores está ligada à especificidade dos problemas da própria investigação filosófica. No entanto, o uso que faço neste trabalho leva em conta, além dessa especificidade da conceitualidade do conceito em Deleuze \& Guattari, a compreensão de relações mais amplas que remetem à própria produtividade do mundo sócio-cultural. No caso, a relação entre os
} 
forma, em resumo, teríamos dois problemas evidenciados por Paloma Vidal na narrativa de estupro: o problema da passividade e o problema da feminilidade, ambos abastecendo uma máquina abstrata específica de rostidade. Como diria Guattari, "o paradigma último da rostidade é um “é assim"" ${ }^{30}$, o que significa dizer que não temos como fugir desses mitos, ou, se preferir, desses problemas, posto que a rostidade nos define. Nosso rosto é pré-fabricado e também ele um modo de dominação: "O rosto é uma política" ${ }^{31}$. Impossível, a partir dessa constatação dos filósofos, não me lembrar de Carol Hanish que, nos anos 1970, publicou um artigo nos EUA com o exato título "The Personal is Political” [O pessoal é político]. Naquela ocasião, o movimento feminista estadunidense era questionado por suas pautas não serem "políticas", visto que tratavam de sexualidade e "assuntos de mulher" e eram encaradas como uma espécie de diálogo terapêutico, no pior sentido da palavra. Então, eu pergunto, já não estariam estes grupos tentando entender como se desencadearia o que aqui estamos chamando de máquina abstrata de rostidade? O rosto é tão pessoal quanto tudo o que o envolve, e "a cabeça e seus elementos não serão rostificados sem que o corpo inteiro não o possa ser, não seja levado a sê-lo, em um processo inevitável" ${ }^{32}$. Processo este passível de ser explorado, como intui mostrar o presente trabalho, também em narrativas de estupro presentes em obras literárias.

Com o intuito de finalizar esta sessão, indico uma nova pergunta, a qual teria por função unir todas as discussões que venho propondo até aqui: qual é,

\footnotetext{
denominados mitos relativos à cultura do estupro, de um lado, e, de outro, aos póprios conceitos que dão possibilidade à cultura do estupro.

${ }^{30}$ Félix Guattari apud François Dosse, Gilles Deleuze \& Félix Guattari: biografia cruzada, 2010, p. 213.

${ }^{31}$ Gilles Deleuze e Félix Guattari, Op. Cit., 2012, p. 55.

${ }^{32}$ Ibidem, p. 39.
} 
então, a imagem de pensamento empreendida por Paloma Vidal em Mar azul com relação à narrativa de estupro? Num primeiro momento, é preciso dizer que os recursos narrativos escolhidos por Paloma Vidal sugerem um alargamento do plano de imanência em que estão inseridos. Esse alargamento faz com que cravemos no muro branco a própria agressão (talvez seja preciso ser mais didática e recorrerei, para isso, à palavra signo neste caso por entender que dentro de tal plano de imanência o sentido de agressão não chega nem a ser concebido, não chega nem a significar algo. Falarei melhor disso na seção seguinte.), a qual posiciona ali mais um tijolo e escorre pelos buracos negros da protagonista. Mas não só. É uma imagem de pensamento que conflui significâncias e subjetividades entre personagens e leitores e por essa razão mesma pode ser dito que a descontinuidade da narrativa se dá por meio de linhas de intensidade que assumem um potencial de máquina de guerra, de resistência. Logo, a narrativa de estupro vira um objeto da máquina de expressão literária.

No caso de Mar azul, poderíamos pensar que a protagonista vive uma crise da terceira idade se não soubéssemos este fato em específico, o estupro. Poderíamos imaginar que a aposentadoria não lhe fez bem, que a vida de uma professora aposentada deve ser muito frustrante, que escrever a reaproxima do pai apenas ou que ela precisava mudar de ares, recomeçar, à maneira de quase todo mundo, bem como que o romance é apenas mais um relato dentre tantos do período ditatorial argentino. No entanto, todas essas sugestões não passariam de buracos negros, pontos de subjetivação no entender dos leitores que assumiriam o estupro como mais um fato, caso a verdade literária de Paloma Vidal tivesse sido escrita de outra forma. Outra forma que, dependendo de quem a escreve, assume um ponto de vista factual antes de criminoso e isso importa tanto que 
Vidal dedicou um romance inteiro à desfiguração da mulher estuprada enquanto sujeito, a ponto da protagonista se manter em constante reterritorialização de seu corpo e de sua mente, uma vez que ambos não mais pertencem somente a ela: "agora eu estou em você para sempre"33 é a frase de $\mathrm{R}$ durante a violação. “Quantas são as lembranças que viram próprias porque delas se pode fazer uma história para si e envelhecer com essa companhia?"34. Dentre tantas histórias das quais teve de se apropriar, a história do estupro faz o caminho inverso e a protagonista não pode mais contá-la, mas ela está lá em meio a todas as outras: é o muro branco de seu buraco negro, ou o buraco negro de seu muro branco.

\section{II.}

Pode parecer improvável relacionar a proposta do corpo sem órgãos às narrativas de estupro na literatura, mas talvez seja mais improvável ainda pensar que dentro do possível rizomático que vem a ser o cerne da esquizoanálise não haveria um ponto em que se pudesse entrar nesta discussão. Desse modo, começo pela afirmação de Deleuze e Guattari de que o corpo sem órgãos "não é uma noção, um conceito, mas antes uma prática, um conjunto de práticas". ${ }^{35}$ Isso significa que é preciso colocá-la em ação, fazê-la funcionar, uma vez que existe corpo sem órgãos em tudo, até mesmo na literatura. E qual seria, então, o organismo deste corpo literário? Isto é, sua organização em decorrência dos estratos que a atravessam? Para responder a essa questão, me reporto à pesquisa

\footnotetext{
${ }^{33}$ Paloma Vidal, Op. Cit., p. 40.

${ }^{34}$ Ibidem, p. 90.

${ }^{35}$ Gilles Deleuze e Félix Guattari, Op. Cit., p. 12.
} 
de Regina Dalcastagnè ${ }^{36}{ }^{37}$ sobre o perfil dos escritores e personagens de romances no cenário literário brasileiro. Segundo o seu levantamento, "os homens são quase três quartos dos autores publicados: 120 em 165, isto é, $72,7 \%$ "38 e, quanto às personagens, "além de serem minoritárias nos romances, as mulheres têm menos acesso à voz - isto é, à posição de narradoras - e ocupam menos as posições de maior importância" ${ }^{\prime 3}$. Também é importante destacar em relação a essa pesquisa que

[...] o único tipo de relação que aparece na maioria das personagens são as amorosas e familiares, mas aí a diferença entre homens e mulheres é significativa - quase $90 \%$ das personagens femininas mantêm relações amorosas e familiares, proporção que cai para pouco mais de três quartos no caso dos homens. As mulheres aparecem mais no papel de cônjuge (44,8\% contra $36,7 \%$ das personagens do sexo masculino), de amante (17\% contra $11 \%)$, de namorada $(16,8 \%$ contra $12,3 \%)$, de "ex" $(14,6 \%$ contra $9,4 \%)$, bem como de filha (35\% contra $27,21 \%)$, de mãe $(34 \%$ contra $25,7 \%)$ ou de irmã $(22,5 \% \text { contra } 16,2 \%)^{40}$.

Embora limitado dentro de um corpus específico, não é difícil perceber que a mulher tem esse papel também bastante limitado no campo literário. $\mathrm{O}$ levantamento abarca o período entre os anos de 1990 a 2004, mas e hoje, há algo de novo, imprevisto, ao nos depararmos com essas informações? Para responder a essa questão, cito (de maneira arbitrária, sim, mas não menos relevante) a lista

\footnotetext{
${ }^{36}$ Regina Dalcastagné, Literatura brasileira contemporânea: um território contestado, 2012.

${ }^{37}$ Os dados que apresento fazem parte de uma extensa pesquisa de mapeamento do romance brasileiro contemporâneo realizada na Universidade de Brasília. "O corpus da pesquisa atingiu um total de 258 obras, que corresponde à soma dos romances brasileiros do período entre $1990 \mathrm{e}$ 2004, publicados pelas editoras Companhia das Letras, Record e Rocco." Ibidem, p. 156.

${ }^{38}$ Ibidem, p. 158.

${ }^{39}$ Ibidem, p. 165.

${ }^{40}$ Ibidem, p. 169.
} 
de finalistas ao prêmio literário de maior destaque no cenário nacional: o Jabuti. ${ }^{41}$ Das dez obras indicadas no ano de 2017, apenas duas foram escritas por mulheres. Dos três vencedores, uma das autoras indicadas ficou na terceira posição. Dos três títulos, um deles sugere uma representação feminina ao intitular-se "A tradutora", escrito por um homem. O que quero dizer e mostrar é que o corpo literário se faz dentro de uma organização muito clara e, ainda que muitos trabalhos venham se dedicando a expor essas desonestidades e injustiças com a mulher escritora e/ou a mulher escrita ${ }^{42}$, existem questões estruturais que insistem em se manter operantes, existem estratos quase impossíveis de serem suplantados, seja no final do século XX ou na contemporaneidade.

Isso é o real da literatura brasileira em seu mais alto grau, e é a isso que o corpo sem órgãos poderia servir como suporte para a verdadeira função da literatura: conectar-nos com outras experiências de vida ou, como nos disse Deleuze e Guattari:

Fim último da literatura: pôr em evidência no delírio essa criação de uma saúde, ou essa invenção de um povo, isto é, uma possibilidade de vida. Escrever por esse povo que falta... ("por" significa "em intenção de" e não "em lugar de" $)^{43}$.

${ }^{41}$ Dados coletados em: Finalistas: Relação dos classificados para 2a fase. Disponível em: http://premiojabuti.com.br/apuracao/f1/. Acesso em: 10 jan. 2018.

${ }^{42}$ Ver, entre muitos outros: BRANCO, Lucia Castello; BRANDÃO, Ruth Silviano. A mulher escrita. Rio de Janeiro: Lamparina Editora, 2004. DUARTE, Constância Lima et al. (Org.). Arquivos femininos: Literatura, valores, sentidos. Florianópolis: Ed. Mulheres, 2014. DALCASTAGNÈ, Regina; LEAL, Virgínia M. V. (Org.). Espaço e gênero na literatura brasileira contemporânea. Porto Alegre: Zouk, 2015. SCHMIDT, Rita Terezinha. Descentramentos - Convergências: Ensaios de crítica feminista. Porto Alegre: Editora UFRGS, 2017.

${ }^{43}$ Gilles Deleuze e Félix Guattari, Op. Cit., 2010, p. 16. 
Pois a que se destina o corpo sem órgãos senão a essa experimentação num Fora absoluto? Um Fora "que não conhece mais os Eu, porque o interior e o exterior fazem igualmente parte da imanência na qual eles se fundiram"44. O Fora absoluto da literatura brasileira talvez seja esse espaço ocupado por multiplicidades que até então se detinham unívocas. Perceber essas multiplicidades enquanto experimentações faria com que a narrativa de estupro não se tornasse mais um ornamento dentro da obra e pudesse, de outro modo, configurar-se como um problema narrativo, mais um agenciamento nessa máquina de expressão literária. "Reconhecer-se em uma representação artística, ou reconhecer o outro dentro dela, faz parte de um processo de legitimação de identidades, ainda que elas sejam múltiplas" ${ }^{45}$. Reconhecer que existe uma proposta narrativa por meio de recursos estilísticos que validam a voz do agressor ou não, validam a voz da vítima ou não e que isso repercute tanto dentro da obra quanto fora dela: eis o objetivo de se analisar narrativas de estupro. Recursos estes que podem fazer mais dicotomia que rizoma, mais rizoma que dicotomia, a depender das escolhas de cada autor ou autora.

No caso do romance Mar azul, pode-se verificar os estratos do Estado (exército, ditadura militar) e da família (adolescente órfã de pai e mãe), mas principalmente de sua condição de mulher (lembremos de Carol Hanish e o rosto/pessoal político). A protagonista não poderia supor que seria estuprada, mas R poderia e o fez, e da pior forma possível: pela sodomia. Segundo Vigarello, “o crime de sodomia revela ainda mais esse amálgama em que aquele que sofreu é imediatamente pervertido: crime "modelo", a ponto de levar ao extremo a

\footnotetext{
${ }^{44}$ Gilles Deleuze e Félix Guattari, Op. Cit., 2012, p. 21.

${ }^{45}$ Regina Dalcastagné, Op. Cit., 2012, p. 148.
} 
focalização na luxúria e manter a ignorância sobre a violência possível" ${ }^{46}$. Aqui entraria, então, aquele outro problema/conceito de que quem o sofreu também o realizou, em que é necessário haver um distanciamento para que se possa dizer não por meio de outras linhas de intensidade que o subscrevem. Essa negação é justamente o corpo sem órgãos na literatura, a desestratificação por completo dos sujeitos que não são mais sujeitos na obra mas sim casos particulares de enunciação coletiva.

Desse modo, a escrita tem esta dupla função de transcrever os agenciamentos maquínicos e de enunciação, ao mesmo tempo em que os desmonta, sendo que o agenciamento em contiguidade com seu desmonte são um só. ${ }^{47}$ Nesse sentido, a escrita de Paloma Vidal exemplificaria uma maneira de ligar-se às narrativas de estupro tomando como base tanto este Fora absoluto que uniria o interno e o externo, quanto desvendaria a atuação de uma máquina abstrata que se mantém única também tanto dentro quanto fora dos textos, bem como agenciaria uma maneira de manifestar-se sobre ela produzindo aí um corpo sem órgãos, visto que "o corpo sem órgãos não se opõe aos órgãos, mas a essa organização dos órgãos que se chama organismo"48. A narrativa de estupro não deixaria, assim, de existir, uma vez que não podemos nos opor ao fato de que ela realmente existe e se faz presente enquanto sistema muro branco-buraco negro. Com esta análise, alinho minha percepção de tais narrativas às reflexões de Sielke, que afirma: “[...] pode ser mais produtivo desafiar as nossas leituras de estupro ao invés de louvar (enquanto liberdade de expressão) ou censurar

\footnotetext{
${ }^{46}$ Georges Vigarello, Op. Cit., 1998, p. 37.

${ }^{47}$ Gilles Deleuze e Félix Guattari, Kafka: por uma literatura menor, 2014, p. 87.

${ }^{48}$ Idem. Op. Cit., 2012, p. 24.
} 
(enquanto atos e "imagens do mal") as suas representações possivelmente perturbadoras" 49 .

Contudo, uma última pergunta ainda se faz crucial: em vista de tudo o que foi dito, como ler, então, narrativas de estupro? Segundo Deleuze \& Guattari ${ }^{50}$, existem três grandes estratos que dariam forma à máquina abstrata: o organismo, a significância e a subjetivação. Como vimos, o organismo vem a ser a organização orgânica dos órgãos, isto é, o sistema que estratifica. A significância opera por meio do regime de signos e, como havia dito anteriormente, entender a agressão enquanto signo neste contexto já opera uma radicalização da narrativa de estupro, porque a agressão pressupõe dor, sofrimento, e não prazer. No entanto, o corpo sem órgãos vê o significante como inimigo, pois alcançar o corpo sem órgãos nunca é interpretar e, sim, experimentar. Quando proponho a experimentação como forma de ler a narrativa de estupro penso que existe uma homogeneidade de interpretações sobre o fato, mas nunca um alcance de sua contingência. Aqui, a experimentação se faz imprescindível, pois é por meio dela que se produz uma imagem de pensamento durante a leitura a qual coincidiria com a imagem de pensamento da narrativa. As interpretações geram mitos, mas a experimentação gera afinidade sem noções pré-concebidas ou estratos cristalizados. Por último, quanto à subjetivação, “como fazer para nos descolar dos pontos de subjetivação que nos fixam, que nos pregam numa realidade dominante?"51. Nesse sentido,

\footnotetext{
49 " $[. .$.$] it may be more productive to challenge our readings of rape than to either celebrate (as$ free speech) or censor (as "evil images" and acts) its possibly disturbing representations." Sabine Sielke, Reading Rape: The Rhetoric of Sexual Violence in American Literature and Culture, 2002, p. 179 , tradução minha.

${ }^{50}$ Gilles Deleuze e Félix Guattari, Op. Cit., 2012.

${ }^{51}$ Ibidem, p. 26.
} 
entender que toda narrativa de estupro se torna um ponto chave na trajetória de qualquer personagem em textos literários é fundamental, pois se em algum momento da obra o estupro passa a ser visto como algo justificável, ele provavelmente não produziu um corpo sem órgãos, não se desestratificou e consequentemente manteve a máquina abstrata da rostidade viva e plena. No entanto, a narrativa de estupro pode, e deve, funcionar com intensidade $=0$, como matriz produtiva de agenciamentos múltiplos não estratificados para que, em última instância, desterritorialize-se em problema e reterritorialize-se em solução.

\section{Considerações finais}

Como últimos apontamentos em relação à discussão que proponho, gostaria de explicar os meios que me levaram a refletir sobre ela. Enquanto, num primeiro momento, este trabalho havia sido concebido como artigo final para uma disciplina de mestrado inteiramente voltada à obra de Gilles Deleuze e Félix Guattari, por vezes me pareceu equivocado unir as reflexões que já venho desenvolvendo para a escrita da dissertação com os conceitos apresentados pelos autores. Isso porque talvez a leitura de seus textos, a princípio, esteja envolvida, em certa medida, a um aspecto meio clariciano, um sentimento de "ou toca ou não toca"52, isto é, ou você sabe do que eles estão falando ou você não faz a mínima ideia. Contudo, foi o entendimento de que esta filosofia se mantém enquanto um sistema aberto que me permitiu não apenas insistir nas leituras de

\footnotetext{
${ }^{52}$ Referência à fala de Clarice Lispector durante uma entrevista concedida para a TV Cultura no ano de 1977. Disponível em: TV Cultural Digital. Panorama com Clarice Lispector. Youtube, 7 mar. 2012. Disponível em: <https://www.youtube.com/watch?v=ohHP1l2EVnU>. Acesso em: 29 jan. 2018.
} 
seus textos e aprofundá-las - uma vez que eu já havia sido tocada -, como também apropriar-me deles, de modo que minha análise não chega a ser nem introdutória, nem conclusiva: ela segue o caminho do meio, um caminho diferente, dentro deste grande mapa rizomático que vem a ser o caosmos no qual estamos inevitavelmente inseridos. Era o aporte teórico de que eu precisava.

Nesse sentido, se, num primeiro momento, a proposta de analisar narrativas de estupro vinha ao encontro de uma emergência de desmistificação das práticas discursivas presentes em obras literárias, agora ela se faz por meio da compreensão de agenciamentos e imagens de pensamento que trabalham em outro plano, num plano de consistência. Se a literatura estabelece uma relação de elaboração e reiteração desses discursos, produzindo percepções que inscrevem o estupro dentro da cultura de maneira a institucionalizar um comportamento específico em face da subjetividade da mulher, é porque existe, da mesma forma, operações maquínicas com as quais me confrontei ao longo de toda a análise e que, por vezes, não são fáceis de serem problematizadas.

Por fim e como última apropriação das palavras dos filósofos, é preciso perguntar: "que violência se deve exercer sobre o pensamento para que nos tornemos capazes de pensar?"53. Uma violência livre de rostos e estratos, mas que não se situa fora deles. A violência da experimentação enquanto impacto sensorial, ponto de ruptura e linha de fuga. A violência que é diferente da violência sexual porque não opera no físico, nem nos sujeitos, mas exatamente na dobra a caminho de um outro plano de imanência que possa concebê-la enquanto tal. A violência que passa a existir, à custa de sua própria existência.

${ }^{53}$ Gilles Deleuze e Félix Guattari, Op. Cit., 2010, p. 68. 


\section{Referências}

BROWNMILLER, Susan. Against Our Will: men, women and rape. New York: Fawcett Books, 1975.

DALCASTAGNÈ, Regina. Literatura brasileira contemporânea: um território contestado. Vinhedo: Editora Horizonte, 2012.

DELEUZE Gilles; GUATTARI, Félix. O que é a filosofia? São Paulo: Editora 34, 2010.

DELEUZE, Gilles; GUATTARI, Félix. Crítica e clínica. São Paulo: Editora 34, 2011.

DELEUZE, Gilles; GUATTARI, Félix. Kafka: por uma literatura menor. Belo Horizonte: Autêntica Editora, 2014.

DELEUZE, Gilles; GUATTARI, Félix. Mil platôs: Capitalismo e esquizofrenia 2 - v. 3. São Paulo: Editora 34, 2012.

DOSSE, François. Gilles Deleuze \& Félix Guattari: biografia cruzada. Porto Alegre: Artmed, 2010.

FOUCAULT, Michel. A ordem do discurso: aula inaugural no Collége de France, pronunciada em 2 de dezembro de 1970. 12. ed. São Paulo : Loyola, 2005.

GROSZ, Elizabeth. Corpos reconfigurados. Cadernos Pagu, São Paulo, n. 14, p. $45-86,2000$.

GUNNE, Sorcha; THOMPSON, Zoë Brigley. Feminism, Literature and Rape Narratives: violence and violation. New York: Routledge, 2010. 
HANISH, Carol. The Personal is Political: The Women's Liberation Movement classic with a new explanatory introduction. Disponível em:

http://www.carolhanisch.org/CHwritings/PIP.html. Acesso em: 9 jan. 2018.

SIELKE, Sabine. Reading Rape: The Rhetoric of Sexual Violence in American

Literature and Culture, 1790-1990. New Jersey: Princeton University Press, 2002.

VIDAL, Paloma. Mar azul. Rio de Janeiro: Rocco, 2012.

VIGARELLO, Georges. História do estupro: violência sexual nos séculos XVI-XX.

Rio de Janeiro: Jorge Zahar Ed., 1998.

\section{Referência para citação deste artigo}

DÖLL, Karine Mathias. Por uma esquizoanálise das narrativas de estupro: uma leitura de Mar azul (2012), de Paloma Vidal. Revista PHILIA | Filosofia, Literatura \& Arte, Porto Alegre, volume 2, número 1, p. 289 - 315, junho de 2020. 